ten bekannter spanischer Orthopterologen (wie Bolivar 1876, 1897-99, Cazurro 1888) gemeldeten Orthopteren erfaßte. Mit den bereits bekannten Arten sind sie mit Hinweisen zur sie betreffenden Literatur wie Beschreibung, Anatomie, Biologie, Verbreitung, Katalogisierung, systematisch geordnet, dargestellt. Insgesamt sind 345 Arten erfaßt worden. Ein alphabetisches Verzeichnis der behandelten Gattungen und Arten läßt diese rasch auffinden. Ein umfangreiches Literaturverzeichnis beschließt den Katalog. Er vermittelt einen guten Einblick in den Artenreichtum der Orthopterenfauna dieser vielfach noch unberührten Landschaften. Besonders reich an endemischen Arten sind die kanarischen Inseln.

Else Jahn

Mitchell, A. und 5 Mitautoren: Die Wälder der Welt. 1983. Großformat $23,5 \times 30 \mathrm{~cm}, 224$ Seiten, davon 128 vierfarbige und 96 zweifarbige Seiten, insgesamt über 1000 farbige $\mathrm{Ab}$ bildungen (Farbfotos, Zeichnungen und Karten). Hallwag Verlag, Bern und Stuttgart, Linsoneinband mit Schuber, DM 98,- -

Die Bedeutung der Wälder für das Leben auf der Erde steht heute außer Frage. Ihre Erhaltung ist ein vielschichtiges, weltweites Problem. Nicht nur unsere heimischen Wälder mit ihrer Flora und Fauna sind bedroht, auch die großen Regenwaldzonen in Südamerika, Zentralafrika und Südostasien sind längst nicht mehr ein unerschöpfliches Rohstoffreservoir; ihre fortschreitende Dezimierung oder gar Zerstörung hätte unüberseh- bare Folgen für den Wasserhaushalt und das Klima auf der Erde, ganz abgesehen von der Verarmung der Natur, der Ausrottung unzähliger Tier- und Pflanzenarten.

Ein internationales Gremium von Fachleuten, Fachautoren und Illustratoren hat es jetzt unternommen, in einem umfassenden, allgemeinverständlichen Werk eine Bestandsaufnahme der großen Wälder und der verschiedenen Waldarten rund um die Erde vorzunehmen und ein Bild von ihrer Natur, ihrer Tierund Pflanzenwelt, ihrer ökologischen Bedeutung und ihrer Nutzung durch den Menschen zu geben.

Die deutsche Ausgabe dieses überaus reich illustrierten Werkes, das gleichzeitig in mehreren Sprachen verlegt wird, ist kürzlich unter dem Titel "Die Wälder der Welt" erschienen.

Der gewaltige Stoff ist übersichtlich gegliedert und in bewundernswerter Weise inhaltlich und optisch uberschaubar gemacht. Das Grundgerüst bilden drei Hauptabschnitte: „Der Wald einst und jetzt", „Das Reich der Bäume“ (unterteilt in "Nadelwälder", "Tropenwälder", "Gemäßigte Zonen“, „Inselwälder") und "Rohstoffe aus dem Wald". Innerhalb dieser Themengruppen werden die verschiedensten Einzelthemen in Text und Bild behandelt, meist jeweils auf einer Doppelseite, so daß man sich jederzeit schnell über ein bestimmtes Gebiet informieren kann. Insgesamt weist das Werk über 1000 farbige Illustrationen auf: Farbfotos, Zeichnungen und Karten.

Dieses exzellente Werk, das uns die Bedeutung und Gefährdung des Waldes auf der Erde eindringlich vor Augen führt, verdient es, weiteste Verbreitung zu finden! Schw.

Anz. Schädlingskde., Pflanzenschutz, Umweltschutz 57, 24 (1984)

(C) 1984, Verlag Paul Parey, Berlin und Hamburg

ISSN 0340-7330/InterCode: ASUMDT

\title{
Mitteilungen
}

\section{International Congress of Entomology}

The XVIIth International Congress of Entomology will be held in the beautiful city of Hamburg, one of the largest cities of the Federal Republic of Germany, August 20-26, 1984, under the sponsorship of the "Deutsche Gesellschaft für allgemeine und angewandte Entomologie" (DGaaE) ("German Society of General and Applied Entomology"), "Senat der Hansestadt Hamburg" ("Senat of the Hansestadt Hamburg") and the "Deutsche Forschungsgemeinschaft" (DFG) ("German Research Society").

Sessions will be held in the excellent modern facilities of the "Hamburg International Congress Centre" - in the same complex with the "Plaza Hotel Hamburg", adjoining the beautiful park of "Planten un Blomen" - the "International GardenExhibition" was held here a short while ago.

Scientific Program: The tentative program of the XVIIth Congress will include plenary sessions, symposia, regular sessions, poster sessions, film sessions, informal meetings, and general and scientific excursions.

The Congress will cover the following main fields of Entomalogy: Systematics and Phylogeny, Morphology and Functional Morphology, Cytology and Ultrastructure, Physiology, Biochemistry, Ecology and Population Dynamics, Genetics, Developmental Biology, Behaviour, Social Insects, Nature
Conservancy and Protection of Species, Biological Didactics, Agricultural Entomology, Forest Entomology, Toxicology, Resistance and Side Effects of Insecticides, Pathology, Stored Product Entomology, Medical and Veterinary Entomology, Biological Control, Integrated Control, Pesticide Development, Ecological Methods and other themes. All languages can be used, but English will be prefered, because there is no simultaneous translation possible. - Participation: All participants are requested to register for one of the three memberships: full member, associate member and student member. Registration forms are enclosed. - Social and Ladies' Programs: An interesting social program will be proposed for all participants. Also a number of tours and local activities will be arranged for the associate members. - Exhibitions: It is planned to display scientific equipment, insect specimens, photographical expositions, book expositions and periodicals on entomology. -

All future correspondence should be mailed to the undermentioned address.

XVII. International Congress of Entomology

Professor Dr. Berndt Heydemann

(Chairman of the Organizing Committee)

XVII. International Congress of Entomology, Secretary General Dr. Thomas Tischler, Zoologisches Institut, Abt. Angewandte Ökologie/Küstenforschung - Biologiezentrum der Universität Kiel, Olshausenstr. 40/60, D-2300 Kiel 1, Federal Republic of Germany (F.R.G.) 